\title{
Research on Basic Teaching Mode Reform of Computer Major Combined with Major Applications
}

\author{
Zhu Zhang ${ }^{1, a}$, Rong Niu ${ }^{2, b}$ \\ ${ }^{1,2}$ College of Information Engineering, Tarim University, Alar, Xinjiang, 843300 \\ ${ }^{\mathrm{a}}$ email, ${ }^{\mathrm{b}}$ email
}

Keywords: Teaching Mode, Computer Major, Major Applications

\begin{abstract}
This paper analyzes the main problems of non-computer on Computer Basic Education in the Situation universal application-oriented transition period to professional services, proposes a "professional applications-oriented" Computer Basic Teaching Reform constructed to serve professional basic computer curriculum, teaching specific design practices, and news, business management and e-commerce professional to illustrate the basic computer course teaching modules, teaching objectives and teaching the main line design case. It describes the "knowledge modular training program" Teaching Method Practice and performance in basic computer course teaching.
\end{abstract}

\section{Introduction}

"In professional applications-oriented," meaning embodied in two levels: First, when the same course for the creation of different non-computer professionals, teaching content and teaching methods and how to embody the characteristics of combined professional applications; and second, different non-computer professionals what are the different needs of computer basics, how to reflect the needs of professional features. Currently Colleges non-computer professional computer basic education in literacy model to professional services applied transition period, the majority of colleges and universities use for many years of basic computer curriculum of "Computer Culture Foundation + high-level language programming" as the basic framework of the intellectuals layer classification and professional teaching of the profession-oriented applications is not clear.

\section{The Basic Computer Course Analysis}

There are obvious differences in students' computer skills. Mainly students in vocational colleges from all over the school, most students in junior high school have received a better computer education. However, due to our high school computer and information science education is extremely uneven, there are still some areas not yet offer this course, or set up the course, but because of the equipment, teachers and other reasons, the teaching is less effective. This causes the computer when the freshmen level uneven. Specific performance: ${ }^{1}$ more than half of new students at the school before touching or studied computer courses, in which there are a considerable number of students already have some computer skills; ${ }^{\circ}$ the same time, new students and there were a small number of students is never touched a computer; "most students want to learn the Flash animation design, Photoshop image processing, 3D animation courses, while the school offered basic computer application course no interest in learning motivation is low.

Professional differences in computer skills required. Now, thanks to information technology has been widely penetrated into all subject areas, so that each subject itself to the computer program put forward their own demands. But now, non-computer professional vocational college teaching basic computer knowledge is the computer itself as a focus to learn and master, and in conjunction with students less professional, making it difficult to adapt to the various needs of the industry after graduation, in society on uncompetitive.

Hours reduction and lectures to increase the presence of contradictions. In the teaching reform in higher vocational institutions, to promote independent learning, thus reducing a lot of hours of courses; at the same time because of the rapid development of computer technology and other cross-disciplinary integration, and a steady increase in the content of teaching basic computer 
courses. Thus, there is a reduction in the increase of hours of lectures and contradictory, on the one hand leads to teachers teaching task difficult to accomplish, many lectures difficult to complete introduction; the other hand, students also feel that the teacher speaks too fast, not been able to digest and absorb these know how.

Less teacher-student interaction. Classroom Computer Application courses although the use of multimedia teaching methods, but because of the knowledge points and miscellaneous class was small, mainly using the teacher, students listen to the traditional method of education, poor teacher-student interaction, students passive learning, influence the effectiveness of teaching. In the laboratory course, we need to have a relatively large operation, students generally reflect too few hours, unable to proficiency in the classroom, to master skills.

\section{Basic Computer Course System Construction}

The new professional teaching objectives emphasize demand-led, computer-based teaching as the main unit of the implementation, we must fully grasp the professional course requirements. To tie in with the smooth implementation of this work, all aspects of school administration attaches great importance to and support, form the basis of computer teaching guidance committee, members of the Committee by the senior professional experts, has overall responsibility for the work of teaching basic computer guidance and planning.

In constructing the curriculum system, according to the specific situation of our school, the use of hierarchical classification model from the professional division into several broad categories: mechanical, electronic information, economics and management and liberal arts, all kinds of press at three different levels teaching. The first level of teaching students a basic understanding of the information society, a basic understanding of information technology, basic methods using computer information retrieval and information processing control, improve students' information literacy and the ability to use a computer. The second level of teaching students the ability to use computers to solve practical problems. It requires students to master certain programming methods, to master certain basic knowledge of hardware and software, acquire a certain software tools that can solve the initial areas of expertise in practical problems. The two levels of teaching content mainly based on computer application technology, more reflected in the understanding and application of computer knowledge, generally it consists of a computer professional teachers responsible for curriculum development, professional teachers teaching tasks computer and non-computer professional part proficient in computer application technology teacher shared. The third level of teaching students the ability to use computer technology to solve practical problems in the field of professional and pioneering and innovative spirit. This level of teaching, and teaching organically integrated, fully embodied the professional-oriented basic computer teaching philosophy. Teaching content and professional fields closely, emphasizing the use of computer technology to solve practical problems in the professional field. Therefore, this level of curriculum construction and teaching mainly by professional teachers to complete the implementation. Due to pay more attention to students analyze and solve problems and the ability to develop innovative, so the greater use of teaching methods and practice of combining forms, such as teaching, comprehensive experiment, course design, graduation design.

In the clear teaching model, based on a "1 $+\mathrm{X}+\mathrm{Y}$ " curriculum program, configure all levels of curriculum. The "1" is set in Basic Computer Science, as the basic course, the professional must be selected to complete the first level teaching objectives, the implementation of the first year of college. For "X" Setting Algorithmic Language (C / C ++, VB), Software Technology, computer theory and interface technology, Chinese information processing, database technology, Internet technology, computer-aided design based on multimedia technology and application of many courses, each professional according to their application needs to choose. These courses correspond to the completion of the second-level teaching objectives, requiring two universities - the implementation of the third grade. On this basis, further extending the professional direction, the "Y" is set for professional applications elective courses depending on the professional and specialized in different directions, resulting in a coverage of more broadly, focuses on the computer 
in the professional field the latest application technology and the development of cutting-edge, with the completion of the third level of the teaching objectives, the implementation of the University of fourth grade.

Training plan is implemented directly on the basis of teaching should be based on different classes, different professions, different professional training objectives even in different directions and choose the appropriate course curriculum system, develop curriculum implementation meets the requirements of professional training. The following table lists the part of the professional class curriculum teaching basic computer training plan.

We will be teaching basic computer school as a teaching entity, under the unified organization of teaching steering committee to plan. Wherein as the first level of teaching "University Computer Foundation" Students basic computer education is an introductory course on basic computer education plays a vital role. School uniform implementation of teaching management, to develop a unified syllabus (sub-types of science and engineering and liberal arts), a unified examination system, unified configuration experimental resources, unified textbooks, unified organization teaching team to achieve excellent teaching resource sharing, thus ensuring the teaching quality. The second level courses according to the needs of the professional selection, can be set to a required course or elective. Due to the combination of professional applications to design, same course in different professions, and the requirements of the knowledge required to master degree are not the same, you need to set a different outline. This part of the course syllabus should participate in the joint computer science and other professional teachers, curriculum content knowledge unit, mastery, hours allocated, assessment requirements and proper planning to develop a unified computer basic characteristics of a professional syllabus. The third level of the professional courses are implemented, the curriculum and syllabus construction planning department is responsible for the professional.

\section{Innovative Practice of Computer Basic Course}

As science and technology advances, the integration of computer technology and other science and technology, so that research and development are inseparable from various disciplines of computer technology, computer technology basic position increasingly consolidated. Find and solve problems is an innovative start thinking not ban copper, the courage to challenge, dare to explore entrepreneurship is essential. Basic computer course and the specialized course is to train students to combine innovation and entrepreneurship necessary way. Increase Extracurricular Activities and Professional combines by opening experiment, project development training, seminars and other forms of outside seeking to increase the non-computer science students into extracurricular learning basic computer time, such that different majors, can find their own personalized learning. In the project development training, arranged by teachers and professional topics related to the scope, independent topics by students, to learn computer literacy through curriculum design and implement solutions. Throughout the practice, students go through the whole process of project development, the topics, design, implementation, generate reports, reply. In practice, the students independent thinking habits, and small wonder bold spirit of innovation will verify and enhance team spirit.

The Ministry of Education as early as February 2012 on the next issued a "do a good job of national undergraduate teaching engineering innovation and entrepreneurship students training program implementation notice", the notice requires the establishment of a variety of undergraduate research participation, build undergraduate research platform to encourage undergraduate students to participate in various research projects. W Private Universities can use existing research strengths, combined with "mentoring" scientific management, teachers encourage students to actively participate in research project led to stimulate the enthusiasm of students, under the guidance of teachers can participate in the implementation of project tasks, students in the actual implementation process research, and gradually mastered the methods of scientific research, to develop a good research habits, stimulate innovation, cultivate the ability to analyze and solve problems. $\mathrm{W}$ this as the basis, the main focus will involve research projects in basic computer 
courses, the way W frontier presentation to show to students, causing students to think, to enable students to understand the gradual process of learning and deep links between what science

Computer organize students to participate at all levels of internal and external innovation and entrepreneurship contest, W Gao private school contest to promote Basic Computer Teaching. Students in the contest to surgery; and experience, not only to enhance the sense of competition W, $1 \wedge 1$ also improve the ability of students to use computer technology to solve practical problems. Can be cut, said competition is not only for students basic computer knowledge and innovation ability to create test, but also demonstrate basic computer teaching reform achievements, basic computer teaching reform has a role in promoting. For example, course experiment, W can be combined with "Chinese Students Computer Design Competition", "Chinese computer application ability contest Students Challenge Cup" game content and requirements of organizations participating students prepare to take the form of simulation exercises, students achieve innovation and entrepreneurship quality, training students ability of division of labor, the purpose of communication, coordination and organizational skills W Panadol affordability. Through theoretical courses and practical courses combined, standardize and improve the basic computer course teaching, innovation and entrepreneurship education will honor into it.

\section{Conclusion}

Basic Computer Teaching is a complex engineering system both in teaching philosophy or in teaching methods need to continue to reform and innovation. In this reform program, we will be the school's basic computer course as a whole, the establishment of a unified management agencies, unified guiding ideology, unified teaching mode, teaching uniform implementation and management, and Basic Computer Teaching professional application combination. We also continue to explore the future development of the law of basic computer teaching reform in teaching management and quality control system, improve teaching methods and means to strengthen the practice of teaching and improve teaching levels continue to explore practice, to accelerate the process of reforms in basic computer .

\section{Acknowledgements}

Tarim University Principal Fund Project (TDZKSSZD201406).

\section{References}

[1] Bao Kongjun. Non-computer Computer Basic Education Reform [J]. Education and occupation, 2007, (09): 190-191.

[2] Liu Qing. Basic Computer Application Teaching Reform and Practice [J]. Fujian computer, 2008, (05): 19-20.

[3] Liu Jing, Guo Ying. Exploration and professional applications combining computer based teaching mode reform [J]. Computer Education, 2008, (10): 147-148.

[4] Li Haiying. Discussion on the Construction of Basic Computer Teaching in Universities New Model [J]. Education and Vocation, 208 (11): 81-82. 